\title{
Flood and Sustainable Agriculture in the Haor Basin of Bangladesh: A Review Paper
}

\author{
Md. Kamruzzaman ${ }^{1, *}$, Rajib Shaw ${ }^{2}$ \\ ${ }^{1}$ Department of Agricultural Extension Education, Sylhet Agricultural University (SAU), Bangladesh \\ ${ }^{2}$ Graduate School of Media and Governance, Keio University, Japan
}

Copyright $\odot 2018$ by authors, all rights reserved. Authors agree that this article remains permanently open access under the terms of the Creative Commons Attribution License 4.0 International License

\begin{abstract}
The paper provides a deep insight into the agricultural practices and cropping pattern in Haor basin. Boro-Fallow-Fallow is the dominant cropping pattern in entire Haor basin. The paper also examines the characteristics of flood and its effects on agricultural production. It is found that flash flood severely destroy standing boro rice just before harvesting almost every year. The paper focuses the principle interventions taken by different organizations (Government and Non-government) to secure agriculture based livelihood against flood hazard in Haor areas. Most of the government initiatives were found structural whereas non-structural measures were prioritized by non-government organizations. The paper formulates a framework for sustainable agricultural production in Haor basin.
\end{abstract}

Keywords Flood, Sustainable Agriculture, Haor Basin, Bangladesh

\section{Introduction}

The Haor basin in the North-Eastern zone of Bangladesh is an important wetland ecosystem. Haors are large back swamp or bowl-shaped depressions between the natural levees of rivers subject to monsoon flooding every year, mostly found in North Eastern part of Bangladesh, known collectively as Haor basin [1, 2]. There are as many as 423 small or large Haors in Bangladesh. The highest number of Haors (133) falls in Sunamganj district followed by Kishoregonj (122) [3]. The Hakaloki Haor, Sumir Haor, Dakhar Haor, Tanguyar Haor, Gungiajuri Haor, Mukhar Haor, Kaowadighir Haor etc. are the prominent Haors in Bangladesh. In terms of ecosystem, crop production practices, economic activities and over all livelihood of the farmers of Haor areas are quite different from those of the other parts of the country.

In Haor basin, water remains either stagnant or in flash flooding condition during the months of June to November and mainly Boro rice (winter rice cultivated from November to May under irrigated condition) is grown in the Rabi season (between the months mid-November to April) using irrigation. Natural pattern of flooding has created very productive fisheries in the wet season here [4]. The main income of the Haor households is based on single crop cultivation and relevant activities. The people work hard during crop season and try to save to sustain livelihoods during non-crop season which is 5 to 6 months deluge which also obstructs livelihood in many ways. This crop is subject to ecological, geographical and environmental attributes of the Haor area. Specifically, flash floods, hail storms and dry weather cause crop damage. Despite cultivating a single crop and the recurrence of flash floods, the Haor region produces about $20 \%$ of country's total staple food (rice), covers almost one fifth of its total land area and provides livelihood for twenty million people [5].

Flood, especially flash flood causes severe damage to boro rice just before harvesting almost every year [6]. Different Government and non-government organizations are working in Haor areas for long time to uplift the livelihood of Haor inhabitants and overall development of Haor basin. But the boro rice based livelihood is still to be secured here. Since Bangladesh is one of the most disasters prone countries affected by climate change and incidence of flood has significantly increased recent decades in Haors, for ensuring self-sufficiency and food security its Haor basin deserve special attention. Under this situation, this paper examines the characteristics of agriculture practices in Haor basin. This paper also identifies the present effect of flood and its future probability to impact on agricultural production. It also analyzes the measures and strategies taken by government and other non-government organizations. Finally, the paper suggests some of the key recommendations to ensure sustainable agricultural practices in Haor basin. 


\section{Haors in Bangladesh}

The total area of the Haor-type wetland ecosystem in Bangladesh is 80,000 square kilometers. The core Haor area, alternatively referred to as the Haor basin or the Sylhet basin, is estimated to spread over an area of 25,000 square kilometers [7]. The Haor basin is bordered on three sides by the mountain ranges of India, with Meghalaya to the north, Tripura and Mizoram to the south, and Manipur and Assam to the east. The basin extends north to the foot of the Garo and Khasia Hills, and east along the upper Surma Valley to the Indian border [8].

The Haor basin is a mosaic of wetland habitats including rivers, streams and irrigation canals, large areas of seasonally flooded cultivated plains and hundreds of Haors and beels [9]. There are altogether 423 Haors comprising an area of about $8000 \mathrm{~km}^{2}$ situated in seven districts: Sylhet, Moulavibazar, Habiganj, and Sunamganj in the NE, Netrokona and Kishoreganj in the north-central and Brahmanbaria in the central eastern region of Bangladesh $[1,10]$.

The river system of Haor region falls under the Meghna basin [10]. This wet land area is criss-crossed by numerous rivers coming down from the hills of India with huge amount of runoff water frequently causes flash flood and annually causes extensive flood routinely during monsoon [5]. The topography of Haor regions is uneven. Furthermore in terms of geographical elevation they are lower than the normal plain lands. Virtually all of this land is below 8 meters and is flooded for 7- 8 months to depths of 5 meters or more during the monsoon [11].

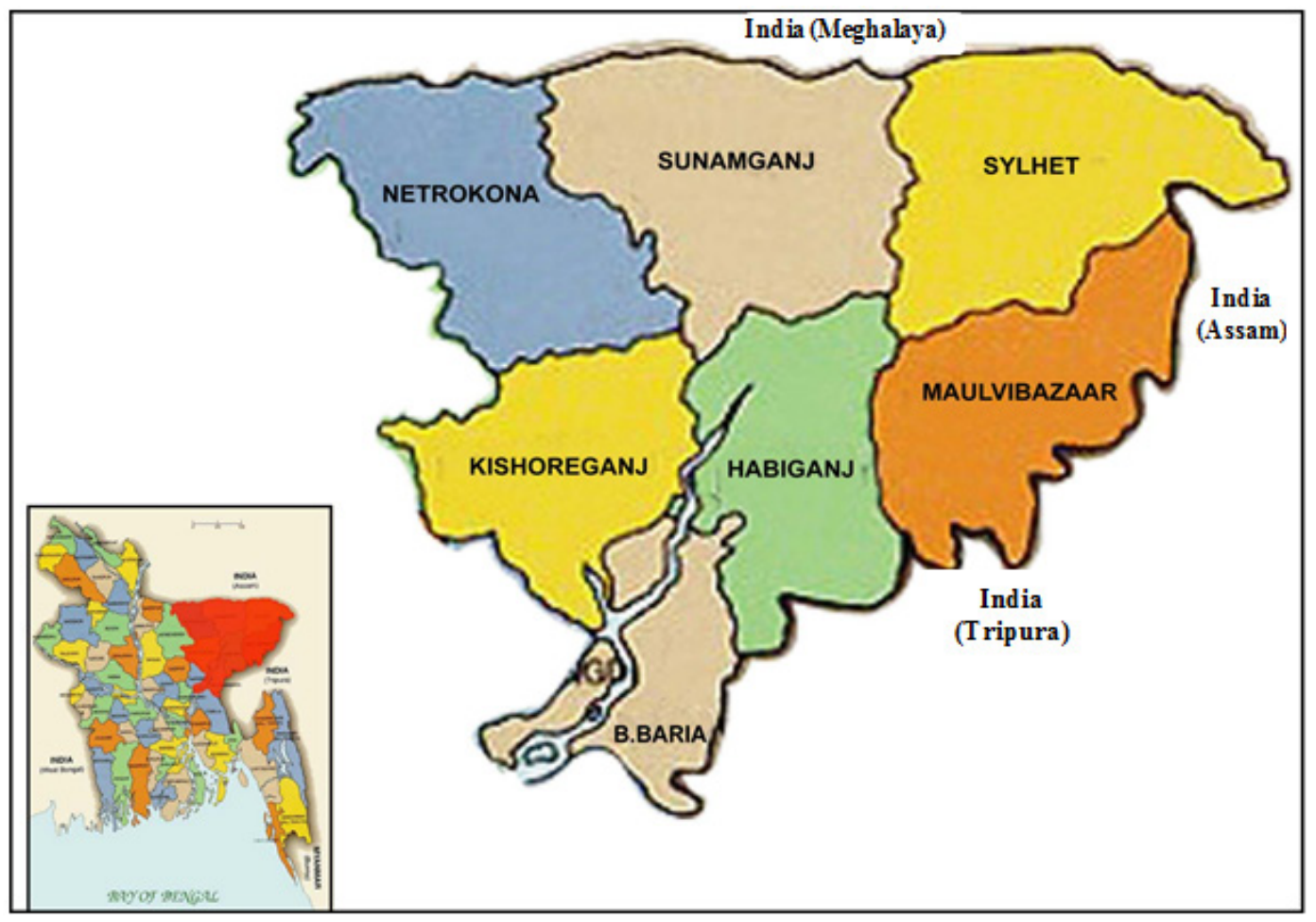

Figure 1. Haor areas in Bangladesh

Table 1. Distribution of Haors and areas under Haor eco-system

\begin{tabular}{|c|c|c|c|c|}
\hline District & Upazila & Total area (ha) & Haor area (ha) & No. of Haors \\
\hline Sunamganj & $\begin{array}{c}\text { Sunamganj Sadar, Jagannathpur, Dharmapasha, Jamalganj, } \\
\text { Chhatak, Derai, Salla, Tahirpur, Bishambarpur }\end{array}$ & 367,000 & 268,531 & 133 \\
\hline Sylhet & Jaintiapur, Beanibazar, Fenchuganj, Balagonj, Biswanath & 349,000 & 189,909 & 43 \\
\hline Habiganj & Ajmerigonj, Hobiganj Sadar, Bahubal & 263,700 & 109,514 & 38 \\
\hline Maulvibazaar & Maulivi Bazar Sadar, Kulaura, Rajnagar, Sreemangal & 279,900 & 47,602 & 4 \\
\hline Netrokona & Atpara, Barhatta, khaliajuri, Mohongonj, Madan, Kandua & 274,400 & 79,345 & 80 \\
\hline Kishoreganj & Mithamain, Karimgonj, Austragram, Itna, Nikli, Bazitpur, & 273,100 & 133,943 & 122 \\
\hline Brahmanbaria & Kuliarchar, Tarail, Bhairab, Katiadi & 192,700 & 29,616 & 3 \\
\hline Total & Bhramanbaria Sadar, Nasirnagar & $1,999,8000$ & 858,450 & 423 \\
\hline
\end{tabular}

Sources: $[12,13]$ 


\section{Agricultural Activities in Haor Basin}

The total cultivated area in seven Haor districts is about 1.26 million hectares of which 0.68 million is under Haor $[3,14]$. Since Haor goes under flooding $(5-10 \mathrm{~m})$ from late May to October, almost $80 \%$ of this area is covered by Boro rice, while only about $10 \%$ area is covered by $\mathrm{T}$. Aman (wet season rice, cultivation period usually from June- July to October- November) production $[14,15]$. It is worthy to mention that Haor areas contribute with $18 \%$ to the national rice production [16]. Basically rice based agriculture is dominant in Haor basin and other crops like potato, groundnut, sweet potato, mustard and pulses are grown in Rabi season to a small extent.

In the Haor areas of major Haor district Sunamgonj and Kishoregonj, more than $80 \%$ of the total cropped areas were covered by Boro-Fallow-Fallow cropping pattern [3]. Boro-Fallow-Fallow is a cropping pattern where crops are grown only in Rabi season (Nov-April) and land remains uncultivated during Aus (April-July) and Aman (July-Nov) season. Only winter crops can be practiced in this cropping pattern. Aus rice (summer rice sown in March or April and harvested during the summer) is not grown in the Haor areas of Sunamgonj, Kishoregonj, Sylhet and Hobigonj [17]. Similarly, in Aman season rice is not grown profusely in the Haor areas of Sunamgonj, Kishoregonj and B.Baria [18]. In Haor basin, a little amount of T. Aus and T. Aman are grown in comparatively higher elevated lands at the side or end of the Haor [3]. Farmers prefer modern varieties over local varieties of rice. Most dominant rice varieties are BRRI Dhan-29, BRRI Dhan-28, BR-19, BR-14, Gochi, Rata etc.

In the Haor basin, there is land (10-40\% of the Haor area varies from Haor to Haor) which is comparatively higher locally known as Kanda. Usually, recession of water from raised kanda lands gets faster and the lands become ready for agricultural activity 30 to 45 days ahead compared to the rice fields (low lying lands). Again, raised kanda lands are inundated lately by flash flood. But unfortunately kanda lands are mostly kept fallow throughout the year. The only difficulty of cultivation in kanda is lack of irrigation facilities $[4,19,20]$.

Table 2. Distribution of cultivated land, land use pattern and cropping intensity of seven Haor districts of Bangladesh

\begin{tabular}{|c|c|c|c|c|c|c|c|c|}
\hline \multirow[b]{2}{*}{ District } & \multirow{2}{*}{$\begin{array}{c}\text { Total } \\
\text { cultivated land } \\
(\text { million ha) }\end{array}$} & \multirow{2}{*}{$\begin{array}{c}\text { Land area } \\
\text { under Haor } \\
\text { (million ha ) }\end{array}$} & \multicolumn{2}{|c|}{ Cultivated land under Haor } & \multicolumn{3}{|c|}{$\%$ of cropped area under } & \multirow{2}{*}{$\begin{array}{c}\text { Cropping } \\
\text { intensity } \\
(\%)\end{array}$} \\
\hline & & & (million ha ) & $\begin{array}{c}\% \text { of Haor } \\
\text { area }\end{array}$ & $\begin{array}{c}\text { Single } \\
\text { cropping }\end{array}$ & $\begin{array}{c}\text { Double } \\
\text { cropping }\end{array}$ & $\begin{array}{c}\text { Triple } \\
\text { cropping }\end{array}$ & \\
\hline Sunamgonj & 0.20 & 0.18 & 0.14 & 78 & 44 & 23 & 3 & 143 \\
\hline Kishoregonj & 0.17 & 0.15 & 0.12 & 80 & 14 & 25 & 12 & 215 \\
\hline Netrokona & 0.21 & 0.14 & 0.09 & 61 & 15 & 29 & 8 & 186 \\
\hline Sylhet & 0.21 & 0.05 & 0.03 & 60 & 28 & 30 & 4 & 160 \\
\hline Hobigonj & 0.19 & 0.04 & 0.04 & 100 & 27 & 27 & 7 & 171 \\
\hline Moulvi Bazar & 0.13 & 0.09 & 0.02 & 22 & 22 & 32 & 5 & 171 \\
\hline B. Baria & 0.15 & 0.03 & 0.01 & 33 & 18 & 29 & 8 & 189 \\
\hline Total & 1.26 & 0.68 & 0.45 & 66 & & & & \\
\hline
\end{tabular}

Source: $[3,14,17]$

Table 3. Major Cropping patterns and area coverage ( $000 \mathrm{ha})$ by season of different crops in Haor areas

\begin{tabular}{|c|c|c|c|c|c|c|c|}
\hline \multirow{2}{*}{ District } & \multicolumn{3}{|c|}{ Major Cropping patterns* } & \multicolumn{3}{|c|}{ Season** } & \multirow{2}{*}{$\begin{array}{c}\text { \% of area } \\
\text { under each } \\
\text { Haor districts }\end{array}$} \\
\hline & Pattern-1 & Pattern-2 & Pattern-3 & Aus & Aman & Boro & \\
\hline Sunamgonj & $\begin{array}{c}\text { Boro-Fallow-Fallow } \\
\text { (86) }\end{array}$ & Fallow-B.Aman-Fallow (2) & $\begin{array}{l}\text { Fallow-Wheat-Fallow } \\
\text { (2) }\end{array}$ & - & - & $135.89(63)$ & 30 \\
\hline Kishoregonj & $\begin{array}{c}\text { Boro-Fallow-Fallow } \\
(82)\end{array}$ & Wheat-Fallow-Fallow (3) & $\begin{array}{l}\text { G. nut-Fallow-Fallow } \\
\text { (2) }\end{array}$ & - & - & $117.15(94)$ & 26 \\
\hline Netrokona & $\begin{array}{c}\text { Boro-Fallow-Fallow } \\
\text { (78) }\end{array}$ & Mustard-Fallow-Fallow (6) & $\begin{array}{c}\text { Boro-Fallow-T.Aman } \\
(9)\end{array}$ & $4.88(89)$ & $40.56(50)$ & $45.98(62)$ & 20 \\
\hline Sylhet & $\begin{array}{l}\text { Boro-Fallow-Fallow } \\
(60)\end{array}$ & $\begin{array}{l}\text { Fallow-B.Aman-Fallow } \\
(21)\end{array}$ & $\begin{array}{l}\text { Fallow- Fallow-T.Aman } \\
\text { (4) }\end{array}$ & - & $19.65(2)$ & $14.10(60)$ & 7 \\
\hline Hobigonj & $\begin{array}{c}\text { Boro-Fallow-Fallow } \\
(68)\end{array}$ & Boro-B.Aman-Fallow (8) & $\begin{array}{l}\text { B.Aman-Fallow-Fallow } \\
\text { (12) }\end{array}$ & - & 10.00 & $33.00(87)$ & 10 \\
\hline Moulvi Bazar & $\begin{array}{c}\text { Boro-Fallow-Fallow } \\
\text { (64) }\end{array}$ & $\begin{array}{c}\text { Fallow-B.Aman-Fallow } \\
(18)\end{array}$ & $\begin{array}{c}\text { Fallow-Aus-T.Aman } \\
\text { (7) }\end{array}$ & $0.29(72)$ & $6.71(3)$ & $10.28(70)$ & 4 \\
\hline B. Baria & $\begin{array}{c}\text { Boro-Fallow-Fallow } \\
(72)\end{array}$ & Fallow-B.Aman-Fallow (6) & $\begin{array}{c}\text { Boro-Fallow-.T.Aman } \\
\text { (5) }\end{array}$ & - & - & $14.12(72)$ & 3 \\
\hline Total & & & & $4.19(83)$ & $76.92(27)$ & $358.38(73)$ & 100 \\
\hline
\end{tabular}

Source: $[3,14,17]$

*Figures in the parentheses indicate percent of the total area of the patterns

**Figures in the parentheses indicate percent area under Modern Varieties (MVs) 
Table 4. Cultivation of modern Boro varieties and yield ( $\mathrm{t} / \mathrm{ha}$ ) of rice in the Haor areas of Bangladesh

\begin{tabular}{|c|c|c|c|c|c|c|c|c|c|c|c|}
\hline \multirow{3}{*}{ District } & \multirow{2}{*}{\multicolumn{6}{|c|}{ Percent (\%) area covered }} & \multicolumn{5}{|c|}{ Yield (t/ha)* } \\
\hline & & & & & & & \multirow{2}{*}{ Aus } & \multicolumn{2}{|c|}{ Aman } & \multicolumn{2}{|c|}{ Boro } \\
\hline & BR14 & BR19 & BRRI dhan 28 & BRRI dhan 29 & Others & Hybrid & & B. Aman & MV & MV & Hybrid \\
\hline Sunamgonj & 5 & 15 & 15 & 43 & 22 & - & - & - & - & $4.3(2.39)$ & 5.50 \\
\hline Kishoregonj & 14 & 4 & 12 & 49 & 20 & 0.24 & - & - & - & $5.37(2.24)$ & 5.82 \\
\hline Netrokona & 14 & 6 & 20 & 40 & 18 & 0.10 & $3.03(2.38)$ & 2.39 & $4.33(2.58)$ & $5.07(3.03)$ & 6.72 \\
\hline Sylhet & 11 & 13 & 21 & 22 & 31 & 0.34 & - & 2.19 & $4.25(2.88)$ & $4.33(2.46)$ & 5.65 \\
\hline Hobigonj & 3 & 7 & 14 & 52 & 24 & 0.12 & - & 1.84 & - & $4.93(2.39)$ & 5.45 \\
\hline Moulvi Bazar & 6 & 19 & 28 & 27 & 20 & - & $3.10(1.36)$ & 2.13 & $4.09(2.24)$ & $4.10(2.24)$ & 5.78 \\
\hline B. Baria & 6 & 12 & 27 & 40 & 15 & 0.14 & $3.12(1.68)$ & 2.22 & $4.23(2.45)$ & $4.85(2.54)$ & 5.92 \\
\hline
\end{tabular}

Source: $[3,14,17]$

*Figures in the parentheses indicate yield of Local Variety of rice

It is interesting to note that, almost $100 \%$ Haor area of Habiganj district is under cultivation. In Kishoregonj and Sunamgonj districts 80 and $78 \%$ of the Haor areas are under crop cultivation, respectively. On the other hand, in Moulavibazar and B. Baria only 22 and $33 \%$ of the Haor areas are under cultivation, respectively. Overall $66 \%$ of the Haor basin is under crop production [3]. Poor irrigation facility is the major hindrance for expansion of boro rice here.

\section{Flood Affecting Crop Production in Haor Basin}

There are mainly two phases of flood in Haor basin i.e. the early flood (pre-monsoon) phase and the deeply flooded (monsoon) phase. Early flood occurs in April and extend until June where as deeply flood remain from June to November. Early flood results in flash flood causes huge damage to the standing crop of boro rice while deeply flood get little crop in the field to damage [21].

The flashfloods, caused due to sudden flow of rainwater from adjacent Indian Hills of Assam and Meghalaya poses a high risk of damage to the standing winter boro rice crop just 2 to 3 weeks before harvesting [10]. Flashflood remains as the major climate risks to thousands of rice farmers in the region over years. Flash flood occurs in the area almost every year. Severity depends on time and quantity of rainfall in the hill and drain out capacity of main rivers.

Flash floods normally occur between mid-April to May. The duration of flash flood is usually from few hours to few days and carried through the area with enormous flow. The haor region belongs to the Meghna basin and catchment of the Shillong Plateau located to its north across the borders with India, and the Tripura Hills located at its southeastern reaches. The places with the highest recorded rainfall such as Cherrapunjee and nearby Mawsynram (with $>11,000 \mathrm{~mm}$ annual rainfall) are located just north of the Haors located in Netrokona and Sunamganj districts [4]. The Haor basin is fed by numerous rivers rising in these hills and pressure of hilly flow plus rain fed water in the rivers reach to such a level to overflow or wash out the embankments/dams or banks of the river/canal and to enter into the Haor. Siltation has raised the Haor and riverbeds made them unable to hold much water and severity of flash flood intensifies. Early invasion of flash flood causes heavy damage to the standing crops of the Haor leaving no or limited scope for harvesting.

In recent years, flashflood hit Sunamganj district and other Haor areas fifteen days earlier than thirty to forty years back. On the other hand, local farmers switched to cultivate HYV rice from local boro rice variety that are of longer duration. As for example, BRII Dhan- 29 takes about 30 days more time to harvest compared to the local boro rice variety. For this reason, farmer get ten to fifteen days less for boro rice cultivation than thirty years ago. This consequence often invites boro rice subject to flash flood [10].

Flash flood damages crop in Haor alternate years. During the period from 2000 to 2004, Boro crop areas in Sylhet division that has been fully and partially damaged by flash floods were about 4.7 lakh and 3.0 lakh acres respectively. Loss of boro paddy production during these periods was about 5.7 lakh metric tons [22]. In 2003 over $80 \%$ of rice amounting to 0.6 million tons was completely damaged due to flashfloods [4]. In 2007, the Haor basin has lost about 1.30 million tons of rice due to severe flood [23]. In 2010, flash flood took place in April just prior to the boro harvesting season and about 30,000 hectares boro cultivated area were ruined and accounted for a loss of about 150,000 metric tons of rice [24, 25, 26].

During flash floods, sediment transport rates increase significantly of the rivers. Due to high intensity of rainfall in adjacent Indian hills coarser sediment such as big sized stone, boulders etc. start to erode from the hilly catchment area and move along the rivers. Over the years, sediment has got deposited mainly on the riverbed and depressed portion of the Haor. According to local people, about 4 to 5 $\mathrm{m}$ sediment has been deposited in some places on the riverbed, which has created an obstruction for water flow, allowed flood waters to overflow the banks easily [22]. Due to deposition of sediment, the wetland beds have been raised causing scarcity of water in the dry season and ultimately hampering rice production in boro season. 


\section{Future Threats of Flood on Agriculture in Haor Basin}

Haor basin is a tectonic depression and is being pushed down as the Indian plate collides with the Eurasian plate. The Sylhet sub-basin is sinking at $2.1 \mathrm{~cm}$ per year because of down-thrusting under Shillong massif [28]. However, based on analysis of sediment thickness, some say the rate of sinking is much less at 2-4 mm/year [29]. In any case, this sinking will mean that annual flooding will become more extensive.

According to the PRECIS ensemble model outputs (where at least $75 \%$ of the models show agreement), the rainfall volume and runoff in the Haor region and its upstream catchment will be increased by at least $40 \mathrm{~mm}$, $90 \mathrm{~mm}$ and $150 \mathrm{~mm}$ during peak monsoons of $2020 \mathrm{~s}, 2050 \mathrm{~s}$ and 2080s, respectively. Cloud cover is more likely to concentrate over the Meghna catchment, especially over Meghalaya, indicating perhaps higher levels of rainfall and runoff in the Haor influence region. The additional water in the eastern Himalayan rivers, under a business as usual condition, is likely to create drainage congestion, which in turn will aggravate floods. This high intensity floods occurring at higher frequencies will affect livelihoods of Haor inhabitants adversely.

According to the same model outputs, there will be a shift in peak rainfall towards May (away from mid-July to
mid-August), with a decrease in rainfall in August. As a consequence, there will be sharp and short-duration high intensity rainfall events in the neighborhood of Haors, especially during pre-monsoon (i.e., March-April-May period). The anomaly with respect to 1961-2000 baselines will be increasingly higher with time throughout the present century. This will have huge implications in terms of increased possibilities of earlier than usual flash flood with a potential loss of standing crops in the Haor. An analysis of extreme weather indicators such as 'one day maximum rainfall' $(\mathrm{R} \times 1)$ and 'maximum rainfall in five consecutive days' ( $\mathrm{Rx} 5)$ show that with time there will be a general increase in occurrence of short but high-intensity rainfall events in the pre-monsoon triggering multiple episodes of flash floods [10].

Forest in the hilly areas and Haor basins used to slow down the flow of water, and more water were seeped into local soils for storage. Due to increased deforestation (natural \& manmade) in Indian border, Meghalaya Hills and Haor basin, flash flood will hit ten to fifteen days earlier [4]. So flood is a great threat for crop production not only for present time but more for the upcoming future in Haor basin. Since, Boro crops remain standing condition during March-April; an effective early warning system (EWS) for early flood would be key step for future agricultural sustainability here [10].

Table 5. Damage caused by flash flood on crop production in Sunamgonj Haor areas

\begin{tabular}{|l|c|c|c|c|c|}
\hline Year & Flood water entered the Haor & Inundating the boro crops & Extent of damage & $\begin{array}{c}\text { Damaged boro } \\
\text { crop (ha) }\end{array}$ & $\begin{array}{c}\text { Cost of damaged } \\
\text { crops (Lac taka) }\end{array}$ \\
\hline 1996 & 16 March & 18 March & $75 \%$ & 29,822 & 4102.07 \\
\hline 1997 & 22 May & 24 May & $15 \%$ & 9,830 & $1,278.84$ \\
\hline 1998 & 20 May & 23 May & $40 \%$ & 11,579 & $2,365.02$ \\
\hline 1999 & 03 May & 06 May & $45 \%$ & 10,950 & 976.65 \\
\hline 2000 & 28 April & 30 April & $70 \%$ & 1,355 & 420.14 \\
\hline 2001 & 27 April & 30 April & $75 \%$ & 4,963 & $1,899.95$ \\
\hline 2002 & 14 April & 18 April & $70 \%$ & 21,677 & $7,058.16$ \\
\hline 2003 & 27 May & 30 May & $20 \%$ & 20,997 & $8,666.87$ \\
\hline 2004 & 13 April & 15 April & $90 \%$ & 95,402 & $34,860.40$ \\
\hline 2005 & 22 May & 25 May & $15 \%$ & & - \\
\hline
\end{tabular}

Source: [27] 


\section{Interventions Taken to Combat Agricultural Production against Flood in Haor Basin}

Government has taken mostly structural measures against flood in Haor areas to sustain agricultural production. Submersible embankments were constructed in entire Haor system during the 1980s and 1990s to divert/ delay flash flood in crop field. But it has failed to protect crop from flood every year [10]. Dredging of river and canals are done here. For sustainable livelihood development of Haor and wetland people and to maintain biodiversity and ecosystem Bangladesh Haor and Wetland Development Board (BHWDB) was established [9]. Non-structural measures are taken by different organizations (e.g. Bangladesh Rice Research Institute (BRRI), Bangladesh Institute of Nuclear Agriculture (BINA), Bangladesh Agriculture Research Institute (BARI), Department of Agricultural Extension (DAE) to a small extent from the government side to increase crop production in Haor areas. Their services are limited to the small scale demonstration and expansion of probable short duration rice varieties and providing free seeds, fertilizer after flood. An effective flood forecasting early warning system is still to be developed.

On the other hand, different NGOs like CARE Bangladesh (Shouhardo-II project), Oxfam Novib, BCAS, Winrock international, Intercorporation, and CNRS etc. are working in Haor areas to sustain crop production against flood hazard. Their initiatives are basically non-structural. They usually perform motivational work through training and demonstration. They drive farmers to adopt short duration rice varieties and alternate crops to combat flood damage [10]. Some of their techniques got popularity and high adoption among Haor farming community against flash flood. However, at the local level, farmers usually reduce loss of flood risk by early harvesting of immature crop, low investment in terms of inputs, labor on boro rice cultivation etc.

Table 6. Initiatives taken by different agencies to reduce flood hazard on crop production in Haor basin

\begin{tabular}{|c|c|c|}
\hline Government & NGOs & Local/ personal \\
\hline $\begin{array}{l}\text { Construction of earthen submergible embankments across the } \\
\text { Haor region }\end{array}$ & $\begin{array}{l}\text { Providing training on modern rice cultivation } \\
\text { techniques }\end{array}$ & $\begin{array}{c}\text { Early harvesting of immature Boro } \\
\text { rice }\end{array}$ \\
\hline Dredging of rivers and canals & Demonstration of short duration varieties & $\begin{array}{c}\text { Providing less input on rice } \\
\text { cultivation }\end{array}$ \\
\hline $\begin{array}{l}\text { Small scale demonstration of shorter maturing variety such as } \\
\text { BRII Dhan } 28 \text { and BRII Dhan } 45 \text { by BRRI }\end{array}$ & $\begin{array}{l}\text { Motivating to adopt floating bed for vegetable } \\
\text { cultivation }\end{array}$ & $\begin{array}{l}\text { Using kanda land for crops other } \\
\text { than rice }\end{array}$ \\
\hline $\begin{array}{l}\text { Extension of BRRI Dhan } 51,52 \text { by Department of Agriculture } \\
\text { Extension (DAE) for flash flood prone areas in the Aman season }\end{array}$ & $\begin{array}{l}\text { Introducing high value crop e.g. vegetables, } \\
\text { spices, pulses etc. }\end{array}$ & $\begin{array}{l}\text { Early sowing of rice just after } \\
\text { removal of monsoon flood water }\end{array}$ \\
\hline $\begin{array}{c}\text { Emphasis to develop modern Boro rice varieties which can be } \\
\text { grown in a shorter time frame }\end{array}$ & $\begin{array}{c}\text { Creating awareness on flash flood and possible } \\
\text { remedies }\end{array}$ & $\begin{array}{l}\text { Search rice varieties that can be } \\
\text { harvested before flash flood }\end{array}$ \\
\hline Giving free seeds and fertilizers after flood & $\begin{array}{l}\text { Popularizing no-tillage potato cultivation under } \\
\text { water hyacinth mulch in wet sown condition }\end{array}$ & Crop seed preservation \\
\hline Training to farmers to use new crop technologies & Providing credit for agricultural tools, inputs & $\begin{array}{l}\text { Cultivating potato, mustard to a } \\
\text { small extent }\end{array}$ \\
\hline Developing and piloting flood forecasting early warning system & \begin{tabular}{|c|} 
Adapting wetland harvesting plant \\
\end{tabular} & \\
\hline \multirow[t]{6}{*}{$\begin{array}{c}\text { Enable farmers to participate in selected market-based value } \\
\text { chains }\end{array}$} & $\begin{array}{c}\text { Adoption of Murta cultivation and weaving shitol } \\
\text { pati }\end{array}$ & \\
\hline & Inspiring to plant bamboo, Hijol, Koroch etc. & \\
\hline & Introducing short duration hybrid rice & \\
\hline & $\begin{array}{l}\text { Encouraging timely sowing of boro rice with } \\
\text { short duration variety }\end{array}$ & \\
\hline & Use of kanda land for vegetables, spices & \\
\hline & Homestead vegetable and spices cultivation & \\
\hline
\end{tabular}

Source: $[2,4,6,9,10,21,27,28,30]$

\section{Recommended Strategies and Way Forward}

Haor basin contains immense opportunity for agricultural practices and livelihood improvement of its inhabitants. Since most of the land are single cropped and flooded every monsoon, its soil is distinctly more fertile than any other Agri Ecological Zones (AEZ) of Bangladesh. Bumper production in every year and significant contribution to national rice production is the evidence of such productivity in this region. The impact of climate change especially flood is a major threat to sustain productivity and single boro rice crop based livelihood here over the years. The future prediction of flood especially early flash flood due to increased rainfall in Meghna basin has aggravated the overall scenario. Different research findings and field surveys conclude on non-structural measures of flood to ensure sustainable agricultural practices in Haor basin. 
As a consequence, a comprehensive and integrated action plan and effective implementation strategies is to be developed. Bangladesh Haor and Wetland Development Board (BHWDB) can play the leading rule in this regard. Existing research organizations like Bangladesh Rice Research Institute (BRRI), Bangladesh Agricultural Research Institute (BARI), Bangladesh Institute of Nuclear Agriculture (BINA) etc. should concentrate research on Haor based crop technologies to address flood risk. The existing extension policies of Department of Agricultural Extension (DAE) should be restructured and strengthened in Haor basin considering it as a special and unique region. Ministry of Disaster Management and Relief, Bangladesh Meteorological Department (BMT) can share their experience, expertise and strength in this regard.

It is very worthy to mention that the Haor and its neighboring districts have three public universities (Sylhet Agricultural University (SAU) \& Shahjalal University of Science and Technology (SUST) in Sylhet and Bangladesh Agricultural University (BAU) in Mymensingh). Existing Agronomy and Haor Agriculture department of SAU, recently launched Haor Agricultural Research and Development Institute of BAU should focus both fundamental and recent agro-based issues of Haor basin in course curricula and other relevant departments should adopt this topic. The academician of those varsities can devote their research to Haor basin addressing flood and agricultural sustainability with collaboration to government and foreign donors.

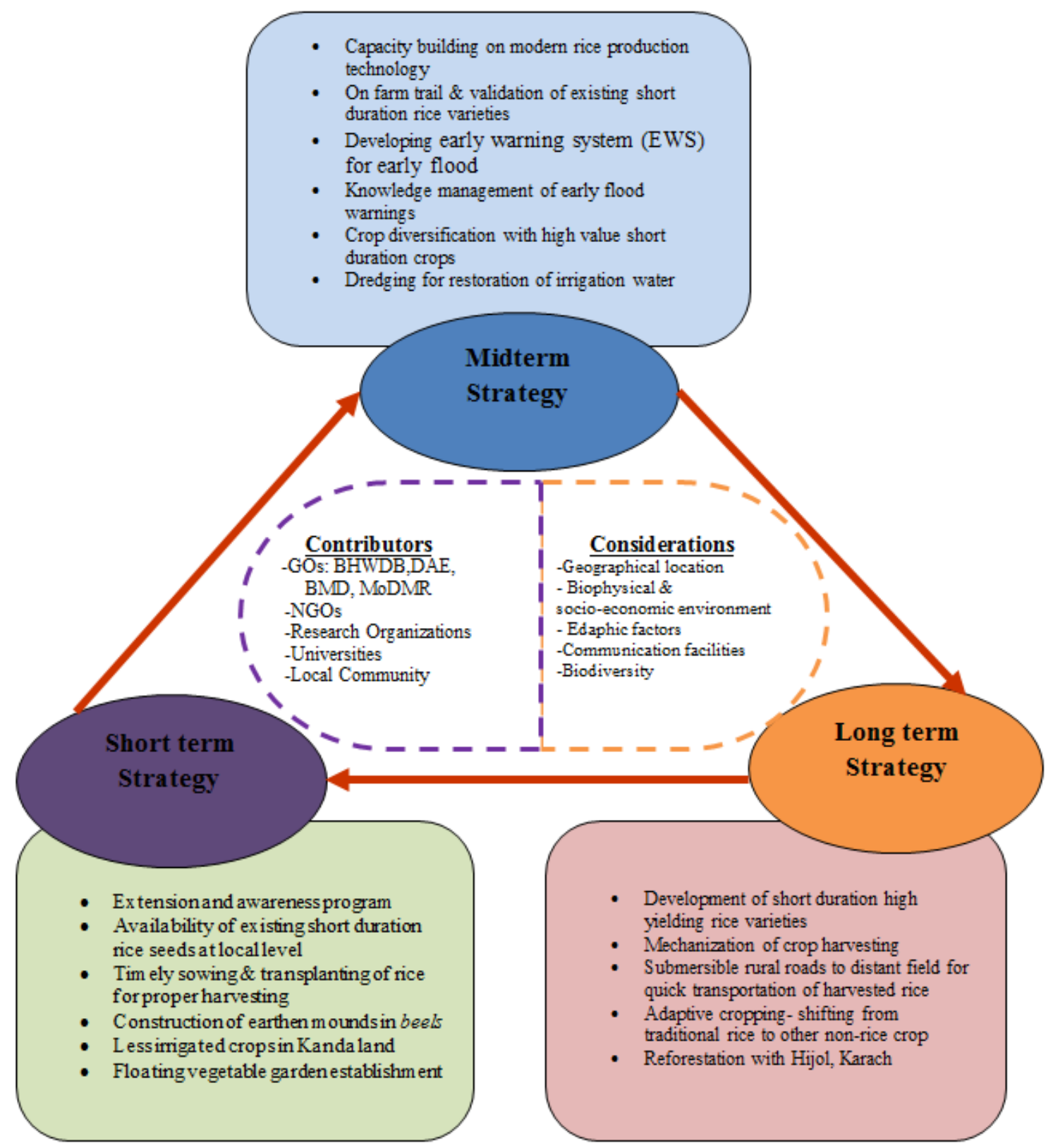

Figure 2. Framework for sustainable agricultural production in Haor basin 
NGOs have significant opportunities in Haor livelihood improvement for their strength to reach to the door step of its beneficiaries and proven performance among Haor community. In all steps of planning and implementation, community participation should be ensured. Geographical location, communication facilities, biophysical and socio-economic environment, edaphic factors, biodiversity etc. must be considered as principal determinants. The pilot program for ensuring sustainable agriculture in Haor basin could be the integration of following short term, midterm and long term strategies.

\section{Short Term Strategies}

- Widespread extension and motivational activities for increased awareness about the present and future threat of flash flood at the grass root level through lecturing, preparing poster, leaflet, booklet, folders.

- To ensure rice based livelihood, quality seeds of existing short duration and submergence variety like BRII Dhan-28, BRII Dhan-52 should be made available at local level. Timely sowing and early boro transplanting should be ensured for punctual harvesting. Construction of earthen mounds in the deep beels to enable the farmers to pile up their paddy even if incoming flash flood start to inundate the beel. This is how more time will be employed to harvest the paddy rather concentrating on immediate transportation to safety. When the water level will rise, the farmers will be able to take their produce home from the temporary killas by using boats.

- Since kanda is lack of irrigation facilities, crops which need less irrigation can bring vast fallow land under production. Alternative Rabi crops can be grown here, for example - pulses, oil seeds, cereals and vegetables etc.

- Establishment of demonstration plot of floating vegetable gardens, providing inputs and training to disseminate and wide adoption among more than six months deeply flooded Haor communities.

\section{Mid-term Strategies}

- Capacity building through field training, motivation as well as cross visits to popularize modern rice production technology amongst the farming communities. On farm trail and demonstration of existing short duration rice varieties and their validation on farmers' field is essential. Introducing Alternate Wet and Dry method (AWD) to increase boro rice coverage in water scarce Haor areas in winter season.

- $\quad$ By combined national action an effective early warning system (EWS) for early flood is to be developed for the farmers of Haor basin.
- Knowledge management of early flood warnings in remote areas among farming communities in Haors. The Haor population's ability to avoid damages could be greatly enhanced if knowledge driven products are developed and shared in right time and using right dissemination language(s) and modalities.

- Indigenous Technical Knowledge (ITKs) and Community Based Adaptation (i.e., CBA) strategies of crop practices to reduce flood risk are to be identified and scientifically approved; environment friendly techniques are to be widely disseminated among Haor communities.

- Crop diversification with high value short-duration vegetables like tomato, cauliflower, pulse crops like mungbean, lentil, spices like onion, garlic and many other cereals and tuber crops that could be harvested much earlier to avoid flash flood.

- Effective dredging of rivers and canals to delay overflow and restoration of irrigation water in Rabi season.

\section{Long Term Strategies}

- Development of eco-system based short duration (110-120 days), high yielding rice varieties for Haor basin to eschew flash flood. Creating awareness, providing loan, institutional support to farmers and farmer cooperatives to introduce and adopt mechanization of cutting paddy that could allow farmers to complete their harvest before the onrush of flash flood water. Expansion of (submersible) rural roads to the distant crop fields to reduce sensitivity of the harvesting process and quick transportation of rice from risky low-lying lands having the threat of flash flood.

- Social and institutional work to sensitize farmers to make a shift from their traditional preference over rice to other non-rice crops thus ensuring adaptive cropping.

- A baseline data is to be collected on the occurrence time of flash flood from seven Haor districts, conduction of district specific time line analysis and preparation of flash flood calendar for judicial cropping pattern and variety selection.

- Environment and eco-system friendly effective submersible embankments should be constructed in early season in flash flood areas so that the flood water can't destroy the standing crops.

- Wide plantation of Hijal (Barringtonia acutangula), Korock (Pongamia pinnata) and other common trees like mandair, mera and barun to maintain eco-system and reduce deforestation in Haor basin. 


\section{REFERENCES}

[1] Miah, M. R. 2013. Enhancing Food Security through Acclimatized Species Domestication in the Haor Region. ABC Journal of Advanced Research, 2(1): 49-65.

[2] Irfanullah, M. H., Azad, M. A. K., Kamruzzaman, M. and Wahed, M.A. 2011. Floating Gardening in Bangladesh: A Means to Rebuild Life after Devastating Flood. Indian Journal of Traditional Knowledge, 10(1): 31-38.

[3] Alam, M. S., Quayum, M. A. and Islam, M. A. 2010. Crop Production in the Haor Areas of Bangladesh: Insights from Farm Level Survey. The Agriculturists, 8(2):88-97.

[4] Climate Change Cell (CCC). 2009. Adaptive Crop Agriculture Including Innovative Farming Practices in Haor Basin. Climate Change Cell, DoE, MoEF; Component 4b, CDMP, MoFDM. June 2009, Dhaka. ISBN: 984-300-003312-5.

[5] Rabby, T. G., Alam, G. M., Mishra, P. K., Hoque, K. E., Nair, S. 2011. Different Economic and Policy Perspectives in Micro Population for Sustainable Development: A Study of the Haor Livelihood in Bangladesh. Afr. J. Bus. Manage, 5(6):2475-2492.

[6] Comprehensive Disaster Management Programme (CDMP 11). 2014. District Level Disaster Management Plan Development, District- Sunamganj. Ministry of Disaster Management and Relief. Government of the People's Republic of Bangladesh.

[7] The World Conservation Union (IUCN). 2007. Communities and Forest Management in South Asia; page 32; ISBN 2-8317-0554-1.

[8] Bennett, S., Scott, D., Karim, A., Sobhan, I., Khan, A. and Rashid, S. M. A. 1995. Interpretive Description of the Region's Wetlands, Wetland Resources Specialist Study, Northeast Regional Water Management Plan, Bangladesh Flood Action Plan 6, Bangladesh Water Development Board.

[9] Hussain and Salam. 2007. Basic Service Delivery Advocacy: Review Report, Development Wheel (DEW), Dhaka.

[10] Ahmed, A. U. 2012. Bangladesh Environmental and Climate Change Assessment. Main report, prepared for IFAD's Country Strategic Opportunities Programme 2012-2018.

[11] NERP. 1995. Specialist Study Wetland Resources, Final Report; Northeast Regional Water Management Project, FAP-6, Flood Plan Coordination Organization, October, 1995.

[12] Asiatic Society of Bangladesh. 2003. Banglapedia, Dhaka.

[13] Master Plan of Haor Area. 2012. Ministry of Water Resources, Government of the People's Republic of Bangladesh.

[14] Huda, M. K. 2004. Experience with Modern and Hybrid Rice Varieties in Haor Ecosystem: Emerging Technologies for Sustainable Rice Production. Twentieth National Workshop on Rice Research and Extension in Bangladesh. Bangladesh Rice Research Institute. Gazipur-1701, 19- 21 April 2004.

[15] Karim, M. M. 2013. Crop Diversification and Intensification in a Village of Dingaputa Haor. M.S. (Ag.Agron.) Thesis, Department of Agronomy, Bangladesh Agricultural University, Mymensingh.

[16] Huq, S., Rahman, A. K. M. A., Ali, S. M. I., Moeller, P. and Gnoyke, P. 2012. Conference Proceedings on 1st National Conference, Community Based Adaptation to Climate Change in Bangladesh Community Based Adaptation to Climate Change in Bangladesh. Bangladesh Centre for Advanced Studies (BCAS), Dhaka, Bangladesh, 08-09 April 2012.

[17] Department of Agricultural Extension (DAE). 2007. Department of Agricultural Extension, Field Crops Wing, Khamar Bari, Farmgate, Dhaka-1215.

[18] Bangladesh Rice Research Institute (BRRI). 2004. Twentieth National Workshop on Rice Research and Extension in Bangladesh. Emerging Technologies for Sustainable Rice Production. Bangladesh Rice Research Institute, Gazipur-1701. 19- 21 April 2004.

[19] Hassan, A. W. R., Aziz, M., Rahman, M. and Talukder, B. A. 2011. Report on Regional Workshop (Inception \& Planning) in Four Climatic Vulnerable Regions of Bangladesh. Disaster and Climate Risk Management in Agriculture (DCRMA) Project (CDMP - II/DAE Part), Department of Agricultural Extension (DAE), Ministry of Agriculture (MoA), Government of the People's Republic of Bangladesh.

[20] Islam, M. A. 2010. Adaptive Crop Agriculture Including Innovative Practices in Haor Basin. Centre for Natural Resource Studies (CNRS), Bangladesh. Proceedings of the South Asia Regional Consultations on Strengthening Climate Resilience through a Climate Smart Disaster Risk Management Approach. Faridabad, Delhi NCR, India, $14-$ 16 June, 2010

[21] HILIP. 2011. Bangladesh: Haor Infrastructure and Livelihood Improvement Project. Main Report, Volume I, Report No.: 2263-BD.

[22] Ministry of Environment and Forests (MoEF). 2012. Second National Communication of Bangladesh to the United Nations Framework Convention to the Climate Change. Government of the People's Republic of Bangladesh.

[23] Sikder, M. A. I. 2013. Climate Change and Bangladesh Agriculture: Country Profile. Submitted as country paper in the Workshop on Developing Farming Systems for Climate Change Mitigation, 26-30 August 2013, Colombo, Sri Lanka.

[24] JNA. 2014. Pre-Disaster Secondary Data. The JNA Consolidation Project, Bangladesh.

[25] Ministry of Environment and Forests (MoEF). 2013. Climate Change and Agriculture in Bangladesh: Information Brief. Government of the People's Republic of Bangladesh.

[26] Islam, M. M., Bhuiyan, M. N. K. and Harun, M. Y. 2012. Development of Value Chain: An Effective Way of Profitable Duck Farming in Haor Areas of Bangladesh. INFPD Good Practices of Family Poultry Production Note No 04.

[27] Center for Natural Resources Studies (CNRS). 2009. Adopting Early Warning System to Address Flash Flood in the Deeply Flooded Haor (Wetland) Basin in North-East 
Bangladesh. Non-Governmental Organization (NGO). Dhaka-1213, Bangladesh.

[28] Johnson and Alan. 1991. Sedimentation and Tectonics of the Sylhet Trough. Geological Society of America Bulletin.

[29] Goodbred and Kuehl. 2000. Enormous Ganges-Brahmaputra
Sediment Discharge during Strengthened Early Holocene Monsoon. Geology.

[30] Rahman, M. H. 2010. Ultra Poor Households' Flood Coping Strategies towards Food Security in Two Flood Prone Regions. National Food Policy Capacity Strengthening Programme, Final Report CF \# 5/08. 